\title{
Callianassa trilobata (Crustacea: Thalassinidea) influences abundance of meiofauna and biomass, composition, and physiologic state of microbial communities within its burrow
}

\author{
Fred C. Dobbs ${ }^{1, *}$, James B. Guckert ${ }^{2}$ \\ ${ }^{1}$ Department of Oceanography, Florida State University, Tallahassee, Florida 32306, USA \\ ${ }^{2}$ Department of Microbiology, Montana State University, Bozeman, Montana 59717, USA
}

\begin{abstract}
Biochemical and traditional methods were used to determine the influence of Callianassa trilobata on microbiological and meiofaunal communities within its large, highly consolidated burrow. Sediment was collected from the lining of the shrimp's burrow, the burrow matrix, and ambient, subsurface sediment. The lining and matrix were composed of poorly sorted, fine-grained material compared to sandy ambient sediment. Meiofauna, predominantly nematodes, were most abundant in ambient sediment, not in the burrow as has been found for other species of macrofauna. Concentrations of chlorophyll a were very high in the lining, consistent with the suggestion that $C$. trilobata lines its burrow walls with seagrass. Analyses of lipids indicated that relative to the matrix and ambient sediment, the lining abounds with pro- and eukaryotic biomass. Thirty-four phospholipid, ester-linked fatty acids (PLFA) were identified and quantified. Fatty acids were assigned to functional groups of microorganisms to assess spatial variations in the absolute abundance and relative proportions of microbial populations. Dominance of prokaryotes was pronounced in all 3 areas, especially the matrix. The lining was the most aerobic location, but anaerobic microhabitats simultaneously allowed proliferation of sulfate-reducing bacteria, e. g. Desulfobacter. A radial trend was detected in the ratio of bacteria with terminally branched PLFA, typical of Gram-positive organisms, to those with unsaturated PLFA common to Gram-negative bacteria. The ratio increased from lining to matrix to ambient sediment. The ratios of trans to cis isomers of $16: 1 \omega 7$ indicated that prokaryotes in the matrix were starved. Through construction and maintenance of its burrow, C. trilobata determines not only the absolute and relative abundances of microbes in its sedimentary environment, but their physiologic state as well
\end{abstract}

\section{INTRODUCTION}

Over a decade ago, Rhoads (1974) and Gray (1974) separately reviewed interactions between benthic macrofauna and marine sediments. Since then, there has been increasingly widespread interest in the effects of benthic organisms on the sedimentary environment. While much has been learned about physical and chemical aspects of bioturbation, research on its microbiological consequences has been comparatively limited in scope. It is recognized, however, that benthic macrofauna, chemistry, and microorganisms constitute a highly interactive triumvirate that determines many of the environmental characteristics of marine sedi-

\footnotetext{
- Present address: Marine Sciences Research Center, SUNY Stony Brook, Stony Brook, New York 11794-5000, USA
}

ments (e. g. Goldhaber et al. 1977, Aller 1982, Aller \& Yingst 1985, Hines \& Jones 1985). Thus, there is a need for information on sedimentary microbes, especially at the level of specific populations, and particularly vis-àvis their interactions with benthic macrofauna.

Tubes and burrows created by infauna are ideal locations for studying macrofaunal-microbial interactions and have been the subject of several detailed investigations. In a classic study, Aller \& Yingst (1978) found high densities of microorganisms and high rates of sulfate reduction in the burrow wall of Amphitrite ornata, a polychaete annelid. Dehydrogenase assays indicated that much of the metabolic activity in the burrow's outer wall was anaerobic. More recently, Aller et al. (1983) found chemical evidence of chemoautotrophic as well as heterotrophic metabolism in the burrows of Onuphis jenneri, a polychaete 
annelid, and Upogebia affinis, a decapod crustacean. Aller \& Aller (1986) recently extended many of their nearshore observations to a deep-sea site, where they also found enhanced biological activity around tubes and burrows.

In laboratory experiments, Dobbs \& Whitlatch (1982) and Aller \& Yingst (1985) reported increased bacterial densities at depth in sediment inhabited by tube-building polychaetes. Detailed natural history observations by Hylleberg (1975) and Reise (1981a, b, 1983, 1987) on sediment-dwelling polychaetes and bivalves confirmed that densities of bacteria, protozoans, and small metazoans often are enhanced in and around organisms' burrows. Alongi (1985) showed that densities of protozoans and rates of bacterial production were greater on tubes of a polychaete than in control sediments, but found no increased densities of bacteria associated with the tubes.

Overall, one concludes that tubes and burrows are sites of intense microbial activity and may harbor abundant populations of microorganisms. However, not all biogenic structures are created equal. Because different species of macrofauna create different microenvironments, it is most reasonable to anticipate (sensu Aller et al. 1983) that the microbiology of biogenic structures will vary among macrofauna.

In the present study, we report on the burrow microbiology of Callianassa trilobata, a deep-burrowing thalassinid crustacean abundant inter- and subtidally along the Gulf Coast of the Florida Panhandle, USA. The primary intent of the research was to move beyond estimates of biomass and to examine the constituent populations of the microbial community. The focus was on description and while traditional analyses were included (e. g. granulometry, meiofaunal counts), the emphasis was on biochemical methods. Such techniques quantitatively extract cellular components having rapid turnover, permitting assessment of the viable microbial community's biomass and composition without the problems associated with direct enumeration or cultural methods (White 1986). The basic approach will be to compare the inner and outer portions of the burrow with themselves and with adjacent, ambient sediment.

\section{MATERIALS AND METHODS}

Organism. A frequent observation in studying callianassids is the difficulty of their capture. In the present study, burrows of Callianassa were abundant at the study site; however, over a 30 mo period, only one individual was collected. Using the key of Biffar (1971), the organism was identified as Callianassa trilobata. Because of the consistent appearance of burrow openings and the uniformity of burrow con- struction at the study site, we assumed that the burrows studied were those of $C$. trilobata.

Suchanek (1985) assigned thalassinids to 3 major ecological types. Callianassa trilobata was not listed specifically by him, but it may belong to the group he termed 'seagrass/algae harvesters'. It does not build surface mounds of excavated sediment. Instead, the openings of its burrow are small (1 to $2 \mathrm{~cm}$ high) rounded protuberances on the sediment surface. Suchanek describes members of this group as 'capturing' and feeding on plant detritus that drifts past their burrow openings. Plant detritus is stored in chambers deep within the long, straight burrow, 'possibly for the subsequent harvesting of bacteria or fungi'.

At the study site, Callianassa trilobata (hereafter Callianassa) builds a permanent, largely vertical, mostly straight burrow that may reach $90 \mathrm{~cm}$ in depth (cf. Biffar 1971). Bifurcations of the burrow were rarely observed. The burrow habitat consists of the lumen, the burrow lining, and the burrow matrix (Fig. 1). The

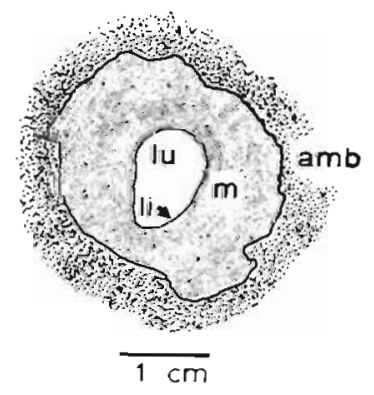

Fig. 1. Callianassa trilobata. Representative cross section through a burrow at a depth of $20 \mathrm{~cm}$ in the sediment. Lu: lumen; li: burrow lining; $m$ : matrix; amb: ambient subsurface sediment

lumen is circular to subelliptical, and at the sediment surface, has a longest cross-sectional dimension of 2 to $5 \mathrm{~mm}$. At a depth of 6 to $15 \mathrm{~cm}$, the lumen rapidly broadens to 7 to $14 \mathrm{~mm}$ in longest cross-sectional dimension. The burrow lining was functionally defined in this study as the smallest thickness of sediment that could be scraped away using the tip of a metal spatula, about $1 \mathrm{~mm}$. The lining is composed of shiny, dark sediment having a relatively high silt-clay content. The burrow matrix is a thick (18 to $36 \mathrm{~mm}$ ) layer of poorly sorted, highly consolidated, dark sediment concentric about the lining and lumen. The outer surface of the matrix is irregular and knobbed.

Field methods. The collection area is an intertidal sand flat in St. George Sound, $50 \mathrm{~m}$ offshore from the Florida State Marine Laboratory, Florida, USA $\left(29^{\circ} 55.00^{\prime \prime} \mathrm{N}, 84^{\circ} 30.36^{\prime \prime} \mathrm{W}\right)$. The flat is composed of moderately well-sorted, medium-fine quartz sand. Siltclay content and organic content are less than $1 \%$ by weight. During the spring-low tide of 28 January 1986, 5 intertidal burrows of Callianassa were partially exca- 
vated and dissected. Samples of uncontaminated sediment were collected from the burrow lining, the burrow matrix, and ambient subsurface sediment, i. e. that not directly affected by the shrimps presence (Fig. 1). Samples were taken from sediment originally 15 to $20 \mathrm{~cm}$ beneath the sediment surface. Water-saturated sediment was below the level at which samples were collected. Sediment was sampled using an ethanolcleaned spatula. Samples for chlorophyll a, phaeopigments, and lipids were transferred to containers that were plunged into liquid nitrogen for several minutes and transported on dry ice to the laboratory. There, samples for lipids were lyophilized immediately; those for photopigments were stored at $-70^{\circ} \mathrm{C}$. Samples for granulometry were taken to the laboratory and frozen. Samples for meiofauna were fixed in the field with $10 \%$ buffered formalin (final concentration ca $5 \%$ ) to which Rose Bengal stain had been added.

Laboratory methods. Analyses of granulometry, meiofauna, photopigments, and lipids were the same as those performed in the companion study (Dobbs \& Guckert 1988).

Statistical methods. Data were analysed using randomized-block, 2-way analyses of variance (ANOVA). The blocking factor was the burrow, the other factor was the location within the burrow, i. e. lining, matrix, or ambient, subsurface sediment. In concert with examining residuals and normal scores for adherence to assumptions of ANOVA, non-additivity was tested for and when necessary, removed through transformation. In general, a $\log _{10}$ transformation was performed, except when the variable was a percentage, in which case an arcsine-square-root transformation was made. Following the ANOVA, Tukey's Honestly Significantly Difference (HSD) test was calculated to compare all means pairwise. Unless otherwise noted, a critical value of $p=0.05$ was used.

\section{RESULTS}

\section{Granulometry}

Median grain sizes of the burrow lining and matrix were in the range of medium sand and did not differ from one another, but each was significantly finer than ambient sand (Table 1). In all cases, but especially in the burrow environment, sorting was poor. As suggested by their appearance, the burrow lining and matrix had a much larger proportion of fine-grained material than did ambient sediment. The silt-clay fraction, particles $<63 \mu \mathrm{m}$ in diameter, accounted for a mean of 13 to $16 \%$ of total sediment weight in the burrow and only $3 \%$ in ambient sediment. For comparison, samples collected the same day from the moderately well-sorted surface sediment had a median grain size of 2.24 phi and a silt-clay content of $0.66 \%$ (Dobbs \& Guckert 1988).

\section{Meiofauna}

The mean abundance of total meiofauna was greater in ambient sediment than in the 2 burrow areas (Table 1). Estimated densities were very low and had a high variance, perhaps in part because the character of the burrow lining and matrix dictated small sample sizes. From a grand total of $49.1 \mathrm{~cm}^{3}$ of sediment, only 88 meiofaunal organisms were recovered. Of these, 53 $(60 \%)$ were nematodes. The density of nematodes followed the pattern detected for total meiofauna, i. e. (highest to lowest) ambient $>$ lining $=$ matrix. The remainder of the meiofaunal organisms included harpacticoid copepods, tardigrades, crustacean nauplii, and annelids

Table 1 Characteristics of the burrow environment of Callianassa trilobata. Values represent the mean (standard deviation) of 5 samples. Results of Tukey's HSD test are indicated by underlines. Values connected by an underline are not significantly different at a family error rate of 0.05

\begin{tabular}{|c|c|c|c|}
\hline Characteristic & Lining & Matrix & Ambient \\
\hline Median phi & $1.86(0.42)$ & $1.80(0.39)$ & $1.54(0.26)$ \\
\hline Silt-clay $(\%)$ & $15.9(8.9)$ & $13.1(7.1)$ & $3.3(4.2)$ \\
\hline Meiofauna (organisms $\mathrm{cm}^{-3}$ ) & $1.22(0.98)$ & $0.63(0.26)$ & $4.53(4.01)$ \\
\hline Nematodes (organisms $\mathrm{cm}^{-3}$ ) & $0.70(0.55)$ & $0.43(0.29)$ & $2.68(2.48)$ \\
\hline Chlorophyll a $\left(\mu \mathrm{g} \mathrm{g}^{-1}\right)$ & $2.64(3.78)$ & $0.31(0.27)$ & $0.27(0.12)$ \\
\hline Phaeopigments ( $\mu \mathrm{g} \mathrm{g}^{-1}$ ) & $5.01(1.58)$ & $2.05(1.38)$ & $1.22(0.41)$ \\
\hline Phospholipid phosphate $\left(\mathrm{nmol} \mathrm{g}^{-1}\right)$ & $135.2(59.4)$ & $28.6(2.2)$ & $18.4(5.5)$ \\
\hline Total PLFA (nmol g $\left.\mathrm{g}^{-1}\right)$ & $53.56(25.45)$ & $5.20(3.46)$ & $4.43(1.64)$ \\
\hline
\end{tabular}




\section{Photopigments}

Estimates of chlorophyll a were about 9 times higher in the lining than in the matrix and ambient sediment (Table 1). The mean value in the lining was slightly greater than that in surface sediments collected at the same time (Dobbs \& Guckert 1988). Concentrations of phaeopigments were 4 times higher in the lining than in ambient sediments; values in the matrix were intermediate. The ratios of phaeopigments to chlorophyll were 2.1 (lining), 5.9 (matrix), and 4.1 (ambient), indicating that significant degradation of chlorophyll had occurred in all locations.

\section{Lipids}

Two estimates of total, viable biomass were obtained, phospholipid phosphate and total phospholipid, esterlinked fatty acids (PLFA). Analysis of each yielded the same qualitative result: biomass of burrow linings was at least 5 times (phospholipid phosphate) and 10 times (PLFA) greater than in burrow matrices and ambient sediments (Table 1). Values for the latter 2 locations were significantly different for phospholipid phosphate but not for total PLFA. By comparison, samples of surface sediment collected the same day had phospholipid phosphate concentrations of about $29 \mathrm{nmol}$ $\mathrm{g}^{-1}$ and total PLFA values of about $15 \mathrm{nmol} \mathrm{g}^{-1}$ (Dobbs \& Guckert 1988).

Thirty-four PLFA were identified and quantified. Fatty acids and their concentrations are listed in the Appendix. Analyses of variance were performed on the log-transformed concentrations of the fatty acids and 32 were significant with respect to location. To adjust for multiple testing, Bonferroni's correction was applied (corrected alpha $=0.05 / 34=0.0015$ ), yielding 25 fatty acids significant with respect to location. A Tukey's HSD test on each of these 25 fatty acids gave the same result. Concentrations in the lining were greater than those in the matrix and ambient sediment, which did not differ from each other (i. e. lining $>$ matrix $=$ ambient). Fatty acids having concentrations not significant with respect to location were: i14:0, 15:1, a15:0, i16:0, a17:0, 16:1w13t, 18:3w6, 18:3w3, and $20: 5 \omega 3$. In every case, however, these fatty acids displayed the same trend noted above; they simply were patchy in their abundance. Overall, the concentrations of individual fatty acids were consistent with the pattern seen in estimates of total biomass.

Three fatty acids were clearly dominant in all locations; $16: 0,16: 1 \omega 7 \mathrm{c}$, and $18: 1117 \mathrm{c}$ together contributed $55 \%$ (lining), $43 \%$ (matrix), and 38\% (ambient) of the fatty acid biomass. Thirteen other fatty acids were among those each comprising $2 \%$ or more (Table 2 ). These 16 dominant fatty acids comprised more than
$80 \%$ of all fatty acid biomass. Analyses of variance were performed on the transformed percentages of the dominant fatty acids and 12 were found significant with respect to location (Table 2 ). Thus, $75 \%$ of the dominant fatty acids varied significantly in their relative contributions to microbial communities among the 3 locations.

Phospholipid fatty acids were combined (by summing their concentrations) to define functional groups

Table 2. Dominant fatty acids $(>2 \%$ of total phospholipid fatty acids in any location) in the burrow lining and matrix of Callianassa trilobata, and in ambient, subsurface sediment ( $n=5$ for each location). Values represent the mean (standard deviation) percent contributed by the fatty acid to total fatty acid biomass. "Fatty acid significantly different with respect to Iocation $(p<0.05)$

\begin{tabular}{|c|c|c|c|}
\hline Fatty acid & Lining & Matrix & Ambient \\
\hline $14: 0$ & $2.17 \pm 0.20$ & $2.31 \pm 0.95$ & $2.59 \pm 0.49$ \\
\hline i15:0 & $3.90 \pm 0.46$ & $5.79 \pm 2.13$ & $6.09 \pm 0.52$ \\
\hline a $15: 0^{\circ}$ & $3.32 \pm 1.64$ & $8.33 \pm 3.53$ & $9.65 \pm 0.77$ \\
\hline $15: 0^{*}$ & $1.47 \pm 0.07$ & $1.89 \pm 0.59$ & $2.40 \pm 0.65$ \\
\hline $16: 1 \omega 9 c^{\circ}$ & $1.69 \pm 0.31$ & $3.26 \pm 0.54$ & $3.39 \pm 0.20$ \\
\hline $16: 1 \omega 7 C^{\circ}$ & $19.76 \pm 1.90$ & $11.11 \pm 1.80$ & $10.50 \pm 1.55$ \\
\hline $16: 1 \omega 5 c^{\circ}$ & $2.18 \pm 0.16$ & $1.65 \pm 0.17$ & $1.33 \pm 0.08$ \\
\hline $16: 0$ & $18.59 \pm 0.81$ & $18.15 \pm 1.30$ & $17.55 \pm 0.78$ \\
\hline $10 \mathrm{Me} 16: 0^{\circ}$ & $5.65 \pm 0.50$ & $5.31 \pm 1.02$ & $3.95 \pm 0.46$ \\
\hline a17:0 & $0.74 \pm 0.37$ & $2.20 \pm 1.26$ & $2.65 \pm 0.93$ \\
\hline $18: 1 \omega 9 c$ & $3.14 \pm 0.53$ & $2.70 \pm 0.67$ & $3.53 \pm 0.51$ \\
\hline $18: 1 \omega 7 c^{\circ}$ & $16.90 \pm 2.54$ & $13.86 \pm 3.98$ & $10.08 \pm 1.27$ \\
\hline $18: 0^{\circ}$ & $2.83 \pm 0.29$ & $3.71 \pm 0.65$ & $4.02 \pm 0.31$ \\
\hline $20: 406^{\circ}$ & $1.59 \pm 0.68$ & $1.33 \pm 0.64$ & $2.31 \pm 0.67$ \\
\hline $20: 5 \omega 3^{\circ}$ & $1.29 \pm 0.48$ & $0.66 \pm 0.58$ & $2.34 \pm 1.40$ \\
\hline $20: 0$ & $0.67 \pm 0.22$ & $2.14 \pm 2.30$ & $0.82 \pm 0.19$ \\
\hline
\end{tabular}

of microorganisms. Biomarker assignments are detailed in Dobbs \& Guckert (1988). Also used in the present study were the terminally branched fatty acids i15:0, a15:0, i17:0, and a17:0, indicative of Bacillustype, Gram-positive bacteria (Kaneda 1977).

The relative contributions of functional groups of microbes to the entire suite of fatty acids are shown in Figs, 2, 3, and 4. Tabular, statistical summaries of within-group, among-location differences are presented in Table 3. In all 3 locations (lining, matrix, and ambient sediment), the fatty acid profiles were dominated $(>35 \%)$ by biomarkers characteristic of prokaryotes (Fig. 2). Fatty acids characteristic of eukaryotes contributed less than $8 \%$ to the profiles. The relative proportions of eu-and prokaryotic markers were lowest and highest, respectively, in the matrix. It follows that the ratio of eukaryotes to prokaryotes was lowest in the matrix. The relative importance of eukaryotes was highest in ambient sediment, as was the ratio of eu- to prokaryotes.

A large portion of the prokaryotic signal was com- 


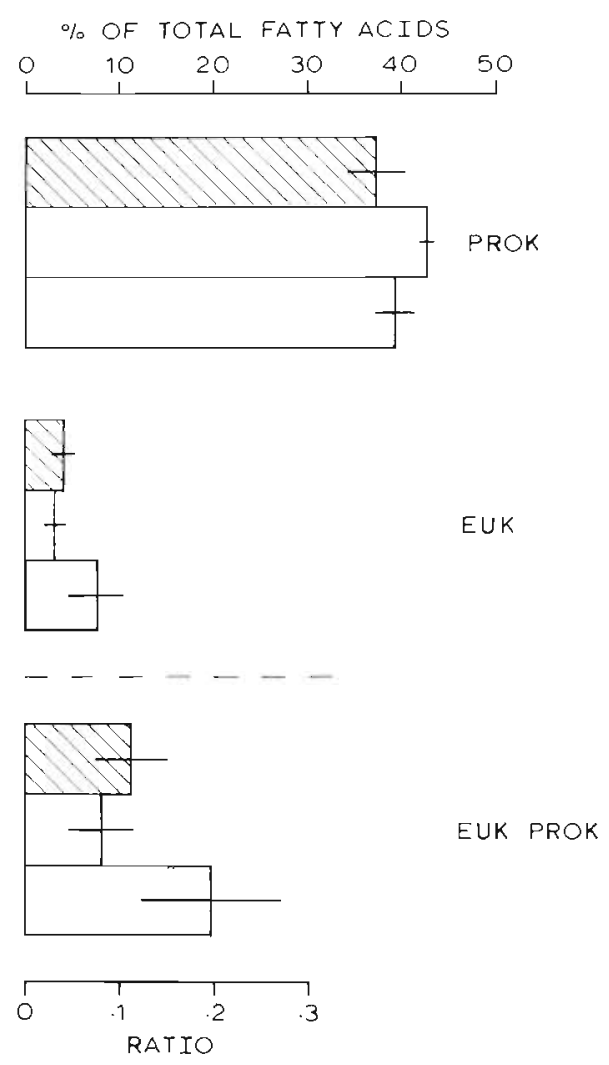

Fig. 2. Relative contributions of prokaryotic (PROK) and eukaryotic (EUK) fatty acid markers, and their ratios to one another, in the burrow lining (hatched) and burrow matrix (clear) of Callianassa trilobata and in ambient subsurface sediment (shaded). Each bar represents a mean and the line bisecting it \pm 1 standard deviation. Dashed line separates histograms indicating percentages from that indicating ratios

posed of $18: 1 \omega 7 \mathrm{c}$, characteristic of, but not unique to, Gram-negative bacteria having the anaerobic-desaturase pathway for producing fatty acids (Fulco 1983). The relative contribution of $18: 1 \omega 7 \mathrm{c}$ decreased stepwise in a radial transect away from the burrow (Table 2) and was significantly lower in ambient sediment than in the burrow lining (Table 3).

The iso- and anteiso-branched fatty acids, typical of Bacillus-type Gram-positive bacteria, had a percent contribution approximately twice as high in the matrix and ambient sediment as in the lining (Fig. 3). The signal for the sulfate-reducing bacteria, Desulfobacter spp., accounted for $>6 \%$ of the fatty acid profiles in the lining and matrix, but was significantly lower in ambient sediment. An opposite trend was found for eukaryotic, photoautotrophic markers. These fatty acids were of greatest relative importance in ambient sediment, where they constituted about $5 \%$ of the total fatty acid biomass.

Eukaryotic markers were separated into w3-'plant' and w6-'animal' groups (Erwin 1973) (Fig. 4). In each, the greatest percent contribution occurred in ambient

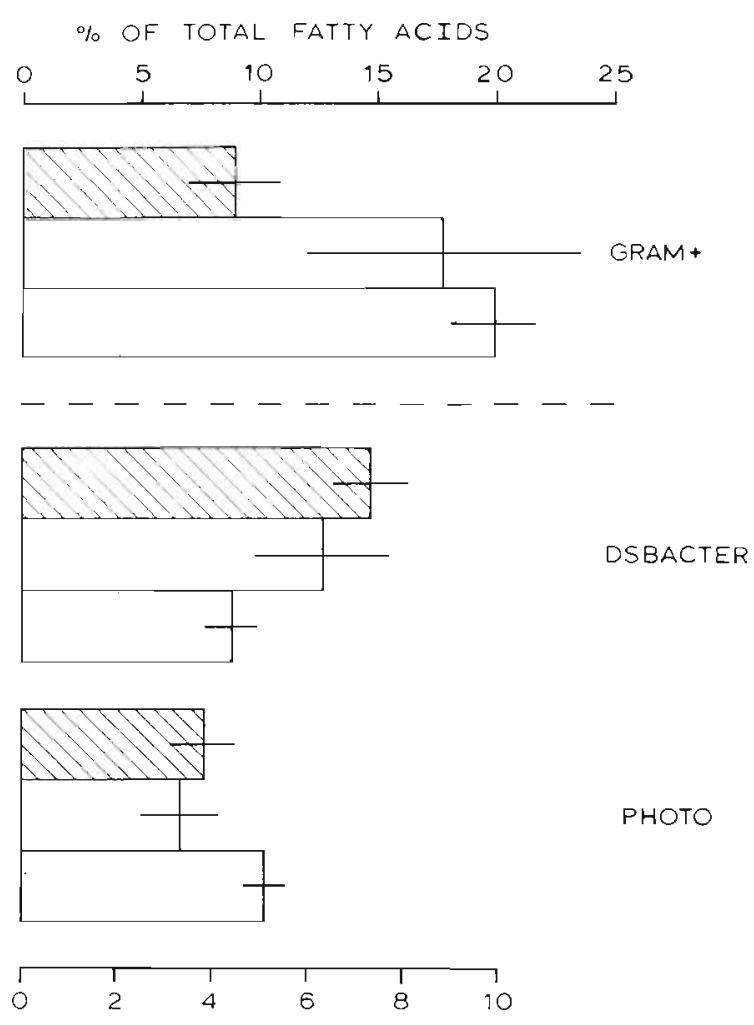

Fig. 3. Relative contributions of fatty acid markers for Grampositive bacteria (GRAM+), Desulfobacter (DSBACTER), and photoautotrophs (PHOTO). As in Fig. 2, except that the dashed line indicates the scale for Gram-positive bacteria differs from the scale for the other groups

sediment, although it was $<4 \%$ of the total biomass. The ratio of $\omega 3$ to $\omega 6$ fatty acids was lowest in the matrix, but this result was not significant at $p \leq 0.05$.

The ratio of trans and cis isomers of individual fatty acids has been suggested as a starvation index for prokaryotes (Guckert et al. 1985, 1986). For 16:1 $107 \mathrm{C}$ and to a lesser extent for $18: 1 \omega 7 \mathrm{c}$, the ratio was highest in the matrix and lowest in the burrow lining (Table 3 , Fig. 5). Similarly, the ratio of cyclopropyl fatty acids to their precursor, monoenoic fatty acids may indicate microbes' physiological state. For both cy $17: 0(\omega 7,8)$ and cy 19:0( $(\omega, 8)$, the ratio to their precursors was greater in the lining and matrix than in ambient sediment. This pattern was not significant, however, for cy 19:0 $(\omega 7,8)$ at $p \leq 0.05$.

\section{DISCUSSION}

\section{Granulometry}

Callianassa trilobata exhibits a remarkable capacity for creating a permanent burrow of a granulometry quite unlike the surrounding sediment. When 


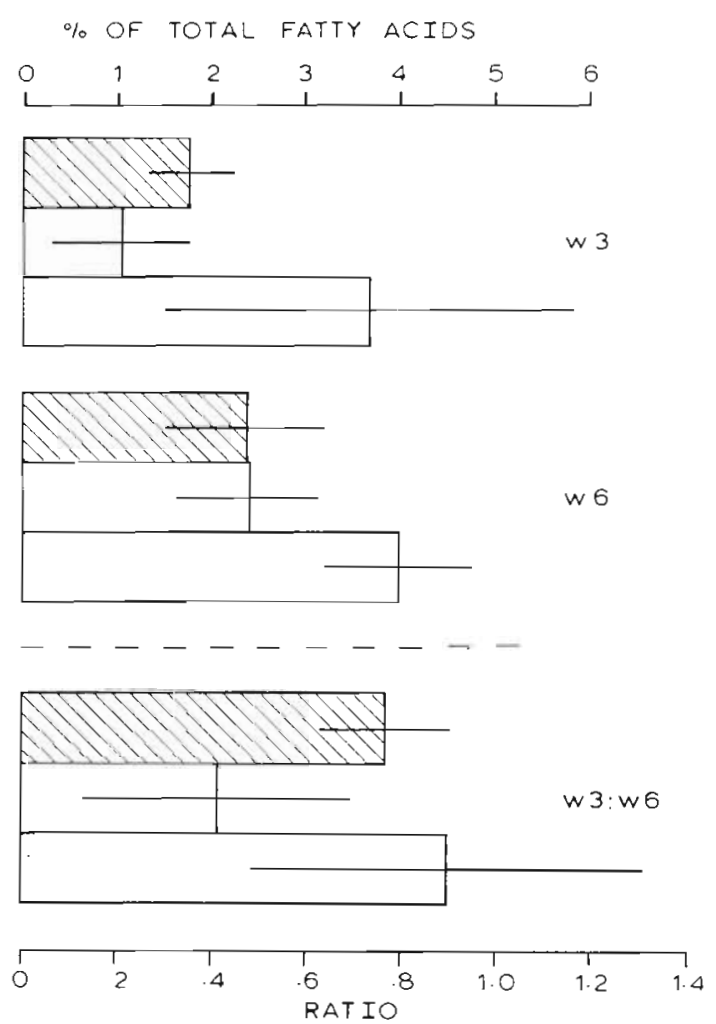

Fig. 4. Relative contributions of $\omega 3$ - and $\omega 6$-fatty acids and their ratio to one another As in Fig. 2

unearthed, the burrow stands out as a conspicuous agglomeration of consolidated, black sediment against grey sand. Callianassa apparently selects silt- and claysized particles from reworked sediments and incorporates them into its burrow. The shrimp may also incorporate fine particles filtered from the copious volumes of seawater with which it irrigates its burrow (e. $\mathrm{g}$. Felder 1979, Colin et al. 1986). The permanent nature of the burrow is realized by paleontologists, who use similar structures constructed by other thalassinids to characterize sea levels and energy regimes of ancient environments (Weimer \& Hoyt 1964, Shinn 1968)

There were no granulometric differences between the burrow lining and burrow matrix, consistent with the idea that the matrix is composed of layers of former burrow linings. Indeed, a cross section of the matrix often reveals visibly distinct arcs of sediment concentric about the lumen. Shinn (1968) reported 'concentric banding' in the burrow matrix of Callianassa spp. As the shrimp grows, the lumen must be expanded (Dworschak 1983), probably through compression of the lining (see Ott et al. 1976, for a description of this behavior by Upogebia litoralis). In the process of widening the lumen, sediment in the matrix would become quite densely packed, consistent with what is observed. A related scheme has been documented for a tube-building polychaete (Aller \& Yingst 1978).
Table 3. Functional groups of microbes and ratios of selected fatty acids in the burrow environment of Callianassa trilobata. In this tabular summary of Tukey's HSD test, letters represent the average percent contribution of the functional group or the average ratio. Values increase from left to right and means connected by an underline are not significantly different at a family error rate of 0.05 . L: burrow lining; $M$ : burrow matrix; A: ambient, subsurface sediment

\begin{tabular}{|c|c|c|c|}
\hline & \multicolumn{3}{|c|}{ Location } \\
\hline & Low & & High \\
\hline \multicolumn{4}{|l|}{ Functional group } \\
\hline Prokaryotes & $\mathrm{L}$ & A & $M$ \\
\hline Gram + bacteria & $\underline{L}$ & $\mathrm{M}$ & A \\
\hline$\omega 6$ series & L & M & $\mathrm{A}$ \\
\hline Photozutotrophs & $M$ & $\mathrm{~L}$ & $\mathrm{~A}$ \\
\hline Eukaryotes & $M$ & $\mathrm{~L}$ & A \\
\hline (1) 3 series & $\mathrm{M}$ & $\mathrm{L}$ & A \\
\hline $18: 1 \omega 7 \mathrm{C}$ & $\mathrm{A}$ & $M$ & $\mathrm{~L}$ \\
\hline \multirow[t]{3}{*}{ Desulfobacter } & $\underline{A}$ & $\mathrm{M}$ & $\mathrm{L}$ \\
\hline & \multicolumn{3}{|c|}{ Location } \\
\hline & Low & & High \\
\hline \multicolumn{4}{|l|}{ Ratio } \\
\hline $16: 1 \omega 7$ (trans/cis) & L & $\mathrm{A}$ & $M$ \\
\hline 18: $1 \omega 7$ (trans/cis) & $\underline{L}$ & $\mathrm{~A}$ & M \\
\hline Eukaryotes/prokaryotes & M & $\mathrm{L}$ & A \\
\hline$\omega 3 / \omega 6$ & $M$ & $\mathrm{~L}$ & A \\
\hline cy $19: 0 / 18: 1 \omega 7 \mathrm{c}$ & $\mathrm{A}$ & M & $\mathrm{L}$ \\
\hline cy $17: 0 / 16: 1 \omega 7 \mathrm{c}$ & A & $\mathrm{L}$ & M \\
\hline
\end{tabular}

\section{Meiofauna}

Mean density of organisms was more than 3 (lining) to 7 (matrix) times lower in the burrow than in ambient sediment (Table 1). This result is quite unlike other studies, in which tubes or burrows of various macrofaunal species have been shown to be focal points of meiofaunal abundance (Aller \& Yingst 1978, Reise \& Ax 1979, Reise 1981a, b, 1983, 1987, Bell 1983, Meyers et al. 1987). The fixation and sorting protocol used in this study was designed for quantitative recovery of 'hard meiofauna, i. e. those having a shell or inelastic cuticle (Hulings \& Gray 1971). Attraction to burrows often has been demonstrated in 'soft' meiofauna (Hulings \& Gray 1971) such as ciliates, platyhelminths, gastrotrichs, and gnathostomulids (e. g. Reise 1983. Meyers et al. 1987). The possibility that these soft taxa are disproportionately abundant in the burrow linings of Callianassa remains to be investigated.

The burrow of Callianassa may be less than optimal for meiofauna simply on the basis of its sedimentary 


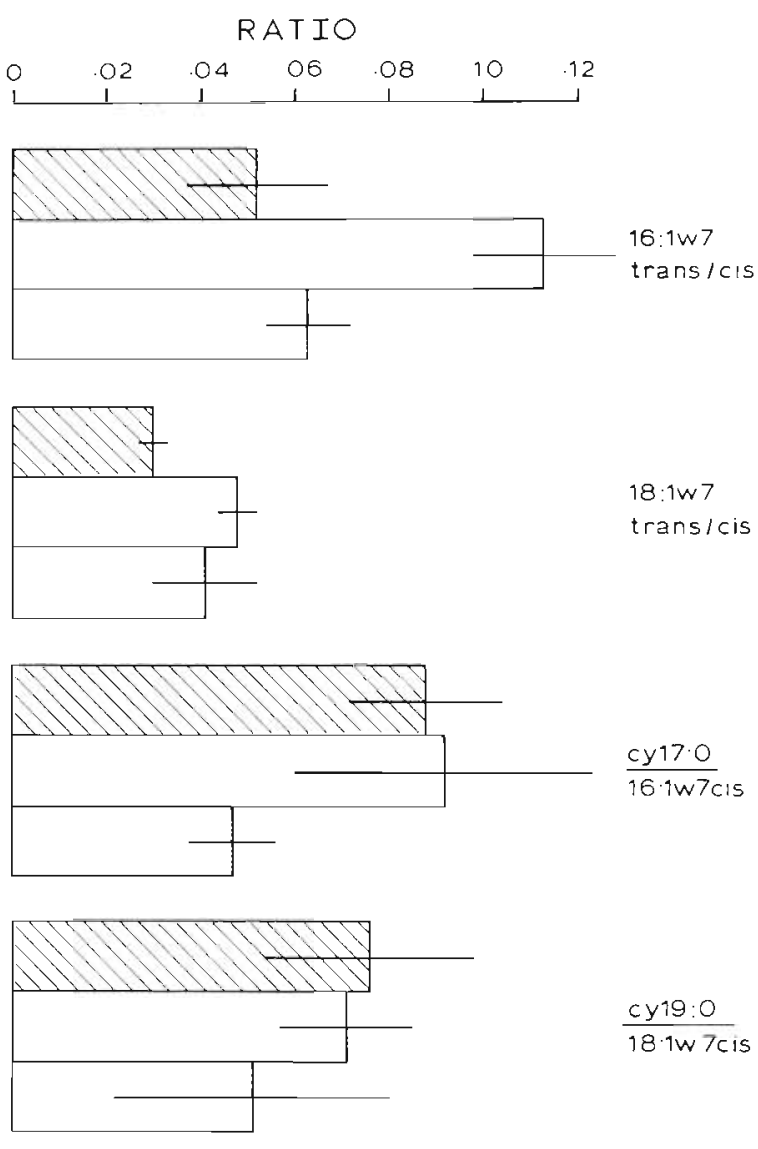

Fig. 5. Ratios of trans and cis isomers of 16- and 18-carbon monoenoic-fatty acids and of cyclopropyl-fatty acids to their precursor 16- and 18-carbon monoenoic-fatty acids. As in Fig. 2

characteristics, specifically, its small grain size, poor sorting, and low pore-water content. Most interstitial animals are restricted to sands having a median grain size not less than 160 to $200 \mu \mathrm{m}$ (Fleeger \& Decho 1987). The degree of pore space afforded by sediment varies according to grain size and sorting and determines not only the upper size limits of interstitial organisms, but their capacity to move about as well. Porewater content also is determined by grain size and sorting and has been described as a 'primary requirement for interstitial life' (Jansson 1967). The burrow lining and matrix of Callianassa are composed of highly consolidated, poorly sorted sediments that cannot have much available pore space or pore water. Thus, the burrow environment simply may be physically inimical to meiofauna relative to ambient sediments.

Only one report of meiofauna in the burrows of other thalassinids is available, and it is indirect. Dworschak (1983) considered that the 'burrowing activity of smaller invertebrates in the walls' of Upogebia pusilla burrows may have been partly responsible for the oxic halo surrounding the shrimps' burrows. In the present study, Callianassa trilobata exhibited no oxic halo around its burrow, underscoring the range of burrow types exhibited by this group of shrimp (Suchanek 1985). Branch \& Pringle (1987) determined that meiofaunal abundances declined in proportion to the density of C. kraussi in field cages, but their study did not specifically address meiofauna in burrows.

\section{Photopigments}

While no light penetrates sediments to the depths sampled $(15$ to $20 \mathrm{~cm}$ ), concentrations of chlorophyll a in the burrow lining were equal to those in surface sediments. Levels of phaeopigments in the burrow lining were about 4 times higher than in surface sediments, indicating a large difference in the amount of degraded plant material. We considered that the finegrained sediment with which Callianassa lines its burrow might be enriched with microphotoautotrophs. However, non-quantitative evaluation of lining sediments with light and scanning electron microscopy revealed no concentration of diatoms or other unicellular algae (F.C.D. unpubl.).

The photopigments may be contained in pieces of vascular plant debris, collected by the shrimp, triturated beyond recognition, and incorporated into the burrow lining. Blades of seagrass have been found in burrows of Callianassa spp. (Shinn 1968, Suchanek 1983, 1985) and of other thalassinids, Upogebia spp. (Ott et al. 1976, Dworschak 1983). Suchanek (1985) described an ecological type of callianassid that captures' detrital plant material and stores it in subsurface chambers. In the present study, beds of Thalassia and Syringodium lie within $20 \mathrm{~m}$ of the burrows, so if Callianassa trilobata is indeed a seagrass harvester, an abundant supply is apparently available.

\section{Lipids}

Phospholipid phosphate and total PLFA, estimates of total microbial biomass, indicated a concentration of microorganisms in the burrow lining. In fact, values of each parameter were more than 4 times higher than in surface sediments sampled the same day. All 34 fatty acids identified in this study exhibited the pattern seen in total biomass, i. e. highest concentrations in the burrow lining and much lower, approximately equal concentrations in the matrix and ambient sediments. Thus, as has been determined for tubes and burrows of other macrofaunal organisms, the burrow lining of Callianassa is a focal point of subsurface, microbial biomass, both pro- and eukaryotic. These results are consistent with the concept that interfaces are the 
environments with greatest microbial biomass (e. g. LaRock et al 1979, Novitsky \& Karl 1986). The much lower biomass in the burrow matrix probably is a consequence of its physical separation from the carbon and energy sources available at the burrow lining.

Analysis of PLFA provides a means of partitioning estimates of total biomass into constituent populations of the microbial community. The 3 overwhelmingly

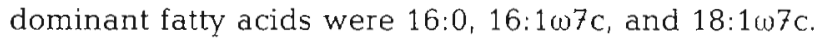
The first is considered ubiquitous in its distribution among microbes and, in fact, exhibited no difference in its relative concentration (17 to $18 \%$ ) among the 3 locations (Table 2). The 2 cis-monoenoic acids decreased in importance along a radial transect away from the lumen, $16: 107 \mathrm{C}$ from about $20 \%$ to $10 \%$, $18: 1 \omega 7 \mathrm{C}$ from $17 \%$ to $10 \%$ (Table 2). Guckert et al. (1985) showed that these 2 acids dominated aerobically grown enrichments of sediments from the study area and were less important in replicate enrichments grown anaerobically. On this basis, the burrow lining would be judged more aerobic than the matrix or ambient sediments, an assessment consistent with occasional inputs of oxygen from Callianassa's irrigation of its burrow with overlying seawater.

If the lining is to be considered relatively aerobic, then how could it also be the site where the anaerobic, sulfate-reducing Desulfobacter spp. flourished? Recall that the lining was functionally defined ('Materials and Methods') as having a thickness of about $1 \mathrm{~mm}$. Given the tightly packed nature of its fine-grained sediment, together with its abundance of microbial biomass, $1 \mathrm{~mm}$ of sediment probably encompasses a variety of microhabitats, some of which would be reducing and allow growth of anaerobic bacteria (cf. Jørgensen 1977, Paerl et al. 1987). Waslenchuk et al. (1983) always found measurable sulfide $(2$ to $26 \mu \mathrm{mol}$ $1^{-1}$ ) in water samples from the burrows of a Bermudan callianassid.

A unifying characteristic of microbial communities from all 3 locations was the predominance of fatty acids characteristic of prokaryotes over those representative of eukaryotes (Fig. 2). This overall trend has been noted in a variety of investigations at the study area (Federle et al. 1983, Findlay \& White 1983, Guckert et al. 1985) as well as in other sediments (Gillan et al. 1983, Gillan \& Hogg 1984). In the present investigation, the ratio of eu- to prokaryotic markers was highest in ambient sediment. Therefore, the burrow environment was dominated by prokaryotes even more than was ambient sediment.

The constituents of prokaryotic dominance were not the same in all 3 locations. This is not to suggest that populations were replaced, since all prokaryotic fatty acids were detected in all samples, but rather, that there were shifts in the relative proportions of popula- tions. For example, a hypothesis can be developed based on the opposite trends in relative abundances of 18:1 $1 \omega 7 \mathrm{C}$, indicative of Gram-negative bacteria, and of iso- and anteiso-branched 15- and 17-carbon fatty acids, indicative of Bacillus-type, Gram-positive bacteria. Of the 3 locations, Gram-positive bacteria were least important in the lining, where abundant carbon and energy resources resulted in proliferation of Gramnegative bacteria. In the matrix, environmental conditions were vastly different. Biomass was much lower and consisted of remnant populations from former burrow linings. Gram-negative bacteria were starved (see the following discussion of the trans/cis ratio), with the result that Gram-positive organisms increased in relative importance. In ambient sediment, Gram-positive bacteria maintained or slightly increased their relative importance, while Gram-negative bacteria continued to decline.

Support for the above contention exists in the literature. In the surface, aerobic layer of sediments, Moriarty \& Hayward (1982) determined that Gram-negative and Gram-positive bacteria existed in a 9:1 ratio. At an anaerobic horizon, the ratio dropped to $7: 3$. Guckert et al. (1985) used sediments from the study site in aerobic- and anaerobic-enrichment cultures. The sediment inoculum contained PLFA indicative of Gram-positive and Gram-negative bacteria, but in the aerobic-enrichment culture, Guckert et al. found no branched-fatty acids and a dominance of monoenoic 16- and 18-carbon acids. The greatest relative concentration of branched acids occurred in anaerobically incubated enrichments, accompanied by decreased importance of the monoenoic acids.

The interpretive powers of phospholipid, esterlinked fatty acids extend beyond identification of functional groups of microbes to predictions regarding their physiologic health. In particular, analysis of the trans and cis isomers of 16 - and 18-monoenoic acids proved useful. The trans/cis ratio of 16:1 107 was much higher in the matrix than in either the lining or ambient sediment (Table 3, Fig. 4). The ratio of 18:1 107 isomers followed a qualitatively similar pattern, although the higher ratio in the matrix was not as pronounced. From these results, we inferred that the prokaryotic community in the matrix was relatively deprived of nutrients and was starved. The rationale for this inference follows.

Trans isomers have been thought by geochemists to result from diagenesis of microbially formed cis-monoenic fatty acids (Volkman \& Johns 1977). However, in vivo synthesis of trans-monoenoic PLFA from acetate occurs in the bacterium Pseudomonas atlantica and the trans/cis ratio increases during its stationary phase of growth (Guckert et al. 1987). Increases in the trans/cis ratio also have been demonstrated in starved cultures of Vibrio cholerae (Guckert et al. 1986). The increased 
ratio presumably was caused by preferential loss of cisrelative to trans-monoenoic fatty acids. As cells starve, they utilize their membrane phospholipids. Without biochemical constraints, utilization would proceed until cell death occurred. However, by analogy to an auxotroph of Escherichia coli (Silbert et al. 1968), V. cholerae was thought enzymatically unable to degrade membrane-bound, trans-fatty acids. Thus, having trans isomers made possible preservation of membrane integrity and survival of lipid degradation induced by starvation (Guckert et al. 1986).

The above results from bacterial monocultures had been observed earlier in enrichment cultures of microbes from estuarine sediments (Guckert et al. 1985). Relative to an aerobic treatment, anaerobically grown consortia exhibited a higher trans/cis ratio. On the basis of these studies, Guckert et al. (1986) proposed using the trans/cis ratio as a starvation index for microbial communities. They hypothesized that openocean ultramicrobacteria would have ratios greater than those in marine and estuarine surface sediments, viz., 0.01 to 0.09 (Volkman \& Johns 1977, Perry et al. 1979, Volkman et al. 1980, Gillan \& Hogg 1984, Guckert et al. 1985). In the matrix of Callianassa's burrow; the ratio was $>0.11$ and significantly greater than in the lining (0.05) and ambient sediments (0.06), locations only millimeters away. The high trans/cis ratio, together with the reasonable assumption that flow of solutes through the highly consolidated sediment is very slow (cf. Aller 1983), leads to the conclusion that the bacteria in the burrow matrix were starved.

On a related point, the ratio of cyclopropyl fatty acids to their cis-monoenoic precursors also provides an indication of prokaryotic, physiologic health. Cyclopropyl fatty acids are formed exclusively by transmethylation of a cis-monoenoic fatty acid esterified to a phospholipid (Law 1971, Marinari et al. 1974). An increase in cyclopropyl acids relative to their precursors occurs as cultures enter stationary phase (Law et al. 1963), as $\mathrm{pH}$ of the medium decreases (Buist \& Findlay 1985), under low oxygen tension, high temperature, and high concentration of magnesium ions (Law 1971). Therefore, cyclopropyl acids apparently form under conditions of physiologic stress, generally when growth has ceased (Thomas \& Batt 1969). Indeed, enrichment of cyclopropyl fatty acids has been demonstrated in starved cultures of Vibrio cholerae (Guckert et al. 1986) and in anaerobically grown enrichment cultures of estuarine sediments (Guckert et al. 1985). In the present study, the ratio of cyclopropyl $17: 0(\omega 7,8)$ to its cismonoenoic precursor, 16:1 $107 \mathrm{C}$, was high in the burrow lining and matrix and low in ambient sediment (Fig. 4). The same trend occurred for cy 19:0 $(\omega 7,8)$ and 18:1 $107 \mathrm{C}_{\text {, }}$ but was not significant at $p \leq 0.05$. These results imply a stress experienced by microbes in the burrow lining and burrow matrix.

Alternatively, the pattern of ratios results from the high concentrations of PLFA indicative of sulfatereducing bacteria in the burrow relative to ambient sediment (Table 3, Fig 3). The PLFA profile of these bacteria inchudes cyclopropyl moieties (Dowling et al. 1986), but the correlation of the stresses mentioned above with cyclopropyl fatty acid synthesis in sulfate reducers is currently unknown.

Appendix. Fatty acid profiles in the burrow lining and burrow matrix of Callianassa trilobata and in adjacent, ambient subsurface sediment. Values are in pmol fatty acid $g^{-1}$ sediment (dry wt) and represent the mean ( \pm 1 standard deviation) of 5 samples

\begin{tabular}{|c|c|c|c|c|c|c|c|}
\hline Fatty acid & Lining & Matrix & Ambient & Fatty acid & Lining & Matrix & Ambient \\
\hline i14:0 & $327 \pm 127$ & $64 \pm 54$ & $51 \pm 19$ & $17: 1 \omega 8 \mathrm{c}$ & $651 \pm 279$ & $58 \pm 57$ & $73 \pm 41$ \\
\hline $14: 0$ & $1135 \pm 463$ & $135 \pm 101$ & $118 \pm 57$ & $17: 1 \omega 6 \mathrm{c}$ & $424 \pm 209$ & $41 \pm 27$ & $37 \pm 19$ \\
\hline i15:0 & $2027 \pm 844$ & $332 \pm 246$ & $269 \pm 99$ & cy $17: 0$ & $995 \pm 610$ & $55 \pm 50$ & $22 \pm 11$ \\
\hline a $15: 0$ & $1774 \pm 1180$ & $480 \pm 366$ & $421 \pm 134$ & $17: 0$ & $638 \pm 288$ & $80 \pm 49$ & $86 \pm 27$ \\
\hline $15: 1$ & $106 \pm 54$ & $15 \pm 12$ & $9 \pm 5$ & $18: 3 u 6$ & $191 \pm 93$ & $32 \pm 32$ & $34 \pm 23$ \\
\hline $15: 0$ & $780 \pm 361$ & $107 \pm 76$ & $108 \pm 49$ & $18: 2 \omega 6$ & $197 \pm 61$ & $24 \pm 17$ & $41 \pm 17$ \\
\hline $116: 0$ & $75 \pm 25$ & $15 \pm 12$ & $14 \pm 6$ & $18: 3 \omega 3$ & $267 \pm 161$ & $24 \pm 21$ & $67 \pm 62$ \\
\hline $16: 109 \mathrm{C}$ & $150 \pm 304$ & $114 \pm 115$ & $167 \pm 59$ & $18: 1 \omega 9 c$ & $1606 \pm 607$ & $129 \pm 78$ & $151 \pm 39$ \\
\hline $16: 1 \omega 9 t$ & $453 \pm 214$ & $28 \pm 19$ & $54 \pm 71$ & $18: 1 \omega^{7} \mathrm{C}$ & $9488 \pm 5596$ & $663 \pm 458$ & $435 \pm 137$ \\
\hline $16: 1 \omega 7 \mathrm{C}$ & $10596 \pm 5001$ & $609 \pm 465$ & $453 \pm 140$ & $18: 1 \omega 7 \mathrm{t}$ & $277 \pm 151$ & $31 \pm 20$ & $18 \pm 7$ \\
\hline $16: 1 \omega 7 t$ & $525 \pm 243$ & $65 \pm 49$ & $29 \pm 13$ & $18: 0$ & $1552 \pm 782$ & $177 \pm 106$ & $179 \pm 71$ \\
\hline $16: 1 \omega 5 c$ & $1147 \pm 522$ & $88 \pm 61$ & $59 \pm 23$ & br19:1 & $280 \pm 136$ & $39 \pm 25$ & $28 \pm 9$ \\
\hline $16: 1 \omega 13 \mathrm{t}$ & $103 \pm 21$ & $16 \pm 17$ & $12 \pm 9$ & cy 19:0 & $674 \pm 382$ & $44 \pm 25$ & $24 \pm 20$ \\
\hline $16: 0$ & $9961 \pm 4696$ & $931 \pm 621$ & $769 \pm 255$ & $20: 4 \omega 6$ & $724 \pm 102$ & $61 \pm 41$ & $109 \pm 74$ \\
\hline 10ME16:0 & $3080 \pm 1633$ & $266 \pm 189$ & $176 \pm 74$ & $20: 5 \omega 3$ & $602 \pm 111$ & $30 \pm 20$ & $121 \pm 116$ \\
\hline $117: 0$ & $548 \pm 228$ & $74 \pm 50$ & $68 \pm 32$ & $20: 0$ & $330 \pm 125$ & $68 \pm 26$ & $38 \pm 23$ \\
\hline a 17:0 & $415 \pm 331$ & $128 \pm 117$ & $113 \pm 50$ & Unidentified & $337 \pm 258$ & $68 \pm 76$ & $49 \pm 30$ \\
\hline $117: 1 \omega 7$ & $424 \pm 184$ & $50 \pm 37$ & $39 \pm 11$ & $\begin{array}{l}\text { Unidentitied } \\
\text { fatty acids }\end{array}$ & $337 \pm 230$ & $08 \pm 70$ & $45-30$ \\
\hline
\end{tabular}


Acknowledgements. We thank D. Balkwill, W. Burnett, P. LaRock, E. Powell, D. Thistle, D. White, and anonymous reviewers for their comments on an earlier version of this manuscript. We appreciate the openness of D. Thistle, D. White, and their coworkers in our use of their laboratories. Our appreciation to those who labored in the field including K. Carman, P. Chin, S. Ertman, M. Foy, T Johengen, J. Martin, and T. Scholly. J. Martin kindly informed us that the burrows were made by Callianassa and identified the shrimp we collected. P. Klein graciously assisted in the preparation of this manuscript. F.C.D. acknowledges financial support from Sigma Xi and a Florida State University Fellowship. This paper is contribution No. 1044 of the Florida State University Marine Laboratory.

\section{LITERATURE CITED}

Aller, J. Y., Aller, R. C. (1986). Evidence for localized enhancement of biological activity associated with tube and burrow structures in deep-sea sediments at the HEBBLE site, western North Atlantic. Deep Sea Res. 33: 755-790

Aller, R. C. (1982). The effects of macrobenthos on chemical properties of marine sediment and overlying water. In: McCall, P. L. Tevesz, M. J. S. (eds.) Animal-sediment relations. Plenum, New York, p. 53-102

Aller, R. C., Yingst, J. Y. (1978). Biogeochemistry of tubedwellings: a study of the sedentary polychaete Amphitrite ornata (Leidy). J. mar. Res. 36: 201-254

Aller, R. C., Yingst, J. Y (1985). Effects of the marine depositfeeders Heteromastus filiformis (Polychaeta), Macoma balthica (Bivalvia), and Tellina texana (Bivalvia) on averaged sedimentary solute transport, reaction rates, and microbial distributions. J. mar. Res. 43: 615-645

Aller, R. C., Yingst, J. Y., Ullman, W J. (1983). Comparative biogeochemistry of water in intertidal Onuphis (Polychaeta) and Upogebia (Crustacea) burrows: temporal patterns and causes. J. mar. Res. 41: 571-604

Alongi, D. M. (1985). Microbes, meiofauna, and bacterial productivity on tubes constructed by the polychaete Capitella capitata. Mar. Ecol. Prog. Ser. 23: 207-208

Bell, S. S. (1983). An experimental study of the relationship between below-ground structure and meiofaunal taxa Mar. Biol. 76: 33-39

Biffar, T. A. (1971). The genus Callianassa (Crustacea, Decapoda, Thalassinidea) in south Florida, with keys to the western Atlantic species. Bull. mar. Sci. 21: 637-715

Branch, G. M., Pringle, A. (1987). The impact of the sand prawn Callianassa kraussi Stebbing on sediment turnover and on bacteria, meiofauna, and benthic microflora. J. exp. mar. Biol. Ecol. 107. 219-235

Buist, P. H., Findlay, J. M. (1985). The biosynthesis of cyclopropane fatty acids. III. $\mathrm{pH}$ dependence of methyl hydrogen exchange: gas chromatographic-mass studies. Can. J. Chem. 63: 971-974

Colin, P. L., Suchanek, T H., McMurtry, G. (1986). Water pumping and particulate resuspension by callianassids (Crustacea: Thalassinidea) at Enewetak and Bikini Atolls, Marshall Islands. Bull mar. Sci. 38: 19-24

Dobbs, F. C.. Whitlatch, R. B. (1982). Aspects of deposit feeding by the polychaete Clymenella torquata. Ophelia 21: $159-166$

Dobbs, F. C., Guckert, J. B. (1988). Microbial food resources of the macrofaunal-deposit feeder Ptychodera bahamensis (Hemichordata: Enteropneusta). Mar Ecol. Prog. Ser. 45: $127-136$
Dowling, N. J. E., Widdel, F., White, D. C. (1986). Phospholipid ester-linked fatty acid biomarkers of acetate-oxidizing sulphate-reducers and other sulphide-forming bacteria. $\mathrm{J}$. gen. Microbiol. 132: 1815-1825

Dworschak, P. C. (1983). The biology of Upogebia pusilla (Petagna) (Decapoda, Thalassinidea) I. The burrows. P.S.Z.N.I: Mar Ecol. 4: 19-43

Erwin, J. A. (1973). Comparative biochemistry of fatty acids in eukaryotic microorganisms. In: Erwin. J. A. (ed.) Lipids and biomembranes of eukaryotic microorganisms. Academic, New York, p. 41-143

Federle, T W., Hullar, M. A., Livingston, R. J., Meeter, D. A., White, D. C. (1983). Spatial distribution of biochemical parameters indicating biomass and community composition of microbial assemblies in estuarine mud flat sediments. Appl environ. Microbiol 45: 58-63

Felder, D. L. (1979). Respiratory adaptations of the estuarine mud shrimp, Callianassa jamaicense (Schmitt, 1935) (Crustacea, Decapoda, Thalassinidea). Biol. Bull. mar. biol. Lab., Woods Hole 157: 125-137

Findlay, R. H., White, D. C. (1983). The effects of feeding by the sand dollar Mellita quinquiesperforata (Leske) on the benthic microbial community. J. exp mar. Biol. Ecol. 72 : $25-41$

Fleeger, J. W., Decho, A. W. (1987). Spatial variability of interstitial meiofauna: A review. Stygologia 3: 35-54

Fulco, A. J. (1983). Fatty acid metabolism in bacteria. Prog. Lipid Res. 22: 133-160

Gillan, F. T., Johns, R. B., Verheyen, T V., Nichols, P. D., Esdaile, R. J., Bavor, J. J., Jr (1983). Monounsaturated fatty acids as specific bacterial markers in marine sediments. In: Bjorny, M. (ed.) Advances in organic geochemistry. Wiley, New York, p. 198-206

Gillan, F. T., Hogg, R. W. (1984). A method for the estimation of bacterial biomass and community structure in mangrove-associated sediments. J. microbiol. Meth. 2: 275-293

Goldhaber, M. B., Aller, R. C., Cochran, J. K., Rosenfeld, J. K., Martens, C. S., Berner, R. A. (1977). Sulfate reduction, diffusion, and bioturbation in Long Island Sound sediments: report of the FOAM group. Am. J. Sci. 277: 193-237

Gray, J. S. (1974). Animal-sediment relationships. Oceanogr. mar. Biol. A. Rev. 12: 223-261

Guckert, J. B., Antworth, C. P., Nichols, P. D., White, D. C. (1985). Phospholipid, ester-linked fatty acid profiles as reproducible assays for changes in prokaryotic community structure of estuarine sediments. F.E.M.S. Microbiol. Ecol. 31: $147-158$

Guckert, J. B., Hood, M. A., White, D. C. (1986). Phospholipid ester-linked fatty acid profile changes during nutrient deprivation of Vibro cholerae: increases in the trans/cis ratio and proportions of cyclopropyl fatty acids. Appl. environ. Microbiol. 52: 794-801

Guckert, J. B., Ringelberg, D. B., White, D. C. (1987). Biosynthesis of trans fatty acids from acetate in the bacterium Pseudomonas atlantica. Can. J. Microbiol. 33: 74.8-754

Hines, M. E., Jones, G. E. (1985). Microbial biogeochemistry and bioturbation in the sediments of Great Bay, New Hampshire. Estuar. coast. Shelf Sci. 20: 729-742

Hulings, N. C., Gray, J. S. (1971). A manual for the study of meiofauna. Smithsonian Contr. Zool. 78: 1-2

Hylleberg. J. (1975). Selective feeding by Abarenicola pacifica with notes on Abarenicola vagabunda and a concept of gardening in lugworms. Ophelia 14: 113-137

Jansson, B. O. (1967). The significance of grain size and pore water content for the interstitial fauna of sandy beaches. Oikos 18: 311-322

Jørgensen, B. B. (1977). Bacterial sulfate reduction within 
reduced microniches of oxidized marine sediments. Mar Biol. 41. 7-17

Kaneda, T (1977). Fatty acids of the genus Bacillus: an example of branched-chain preference. Bact. Rev. 41: 391-418

LaRock, P. A., Lauer, R. D., Schwartz, J. R., Watanabe, K. K. Wiesenburg, D. A. (1979). Microbial biomass and activity distribution in an anoxic, hypersaline basin. Appl. environ. Microbiol. 37: 466-470

Law, J. H. (1971). Biosynthesis of cyclopropane rings. Acc. Chem. Res. 4: 199-203

Law, J. H., Zalkin, H., Kaneshiro, T (1963). Transmethylation reactions in bacterial lipids. Biochim. Biophys. Acta 70: $143-151$

Marinari, L. A., Goldfine, H., Panos, C. (1974). Specificity of cyclopropane fatty acid synthesis in Escherichia coli. Utilization of isomers of monounsaturated fatty acids. Biochemistry 13: 1978-1983

Meyers, M. B., Fossing, H., Powell, E. N. (1987). Microdistribution of interstitial meiofauna, oxygen and sulfide gradients, and the tubes of macro-infauna. Mar. Ecol. Prog. Ser. 35: 223-241

Moriarty, D. J. W., Hayward, A. C. (1982). Ultrastructure of bacteria and the proportion of Gram-negative bacteria in marine sediments. Microb. Ecol. 8: 1-14

Novitsky, J. A., Karl, D. M. (1986). Characterization of microbial activity in the surface layers of a coastal sub-tropical sediment. Mar. Ecol. Prog. Ser. 28: 49-55

Ott, J. A., Fuchs, B., Fuchs, R., Malasek, A. (1976). Observations of the biology of Callianassa stebbingi Borrodaille and Upogebia litoralis Risso and their effect upon the sediment. Senckenberg. maritima 8: 61-79

Paerl, H. W., Crocker, K. M., Prufert, L. E. (1987). Limitation of $\mathrm{N}_{2}$ fixation in coastal marine waters: Relative importance of molybdenum, iron, phosphorus, and organic matter availability. Limnol. Oceanogr. 32: 525-536

Perry, G. J., Volkman, J. K., Johns, R. B. (1979). Fatty acids of bacterial origin in contemporary marine sediments. Geochim. Cosmochim. Acta 43: 1715-1725

Reise, K. (1981a). Gnathostomulida abundant alongside polychaete burrows. Mar. Ecol. Prog. Ser. 6: 329-333

Reise, K. (1981b). High abundance of small zoobenthos around biogenic structures in tidal sediments of the Wadden Sea. Helgoländer Meeresunters. 34: 413-425
Reise, K. (1983). Biotic enrichment of intertidal sediments by experimental aggregates of the deposit-feeding bivalve Macoma balthica. Mar. Ecol. Prog. Ser. 12: 229-236

Reise, K. (1987). Spatial niches and long-term performance in meiobenthic Plathelminthes of an intertidal lugworm flat. Mar Ecol. Prog. Ser. 38: 1-11

Reise, K., Ax, P. (1979). A meiofaunal 'thiobios' limited to the anaerobic sulfide system of marine sand does not exist. Mar Biol. 54: 225-237

Rhoads, D. C. (1974). Organism-sediment relations on the muddy sea floor. Oceanogr. mar. Biol. A. Rev. 12: 263-300

Shinn, E. A. (1968). Burrowing in recent lime sediments of Florida and the Bahamas. J. Paleontol. 42: 879-894

Silbert, D. E., Ruch, F., Vagelos, P. R. (1968). Fatty acid replacements in a fatty acid auxotroph of Escherichia coli. J. Bacteriol. 95: 1658-1665

Suchanek, T. H. (1983). Control of seagrass communities and sediment distribution by Callianassa (Crustacea, Thalassinidea) bioturbation. J. mar. Res. 41: 281-298

Suchanek, T. H. (1985). Thalassinid shrimp burrows: Ecological significance of species-specific architecture. Proc. 5th Int. Coral Reef Symp. Tahiti, Vol. 5: 205-210

Thomas, T. D., Batt, R. D. (1969). Degradation of cell constituents by starved Streptococcus lactis in relation to survival. J. gen. Microbiol. 58: 347-362

Volkman, J. K., Johns, R. B. (1977). The geochemical significance of positional isomers of unsaturated acids from an intertidal zone sediment. Nature, Lond. 267: 693-694

Volkman, J. K., Johns, R. B., Gillan, F. T., Perry, G. J., Bavor, H. L., Jr (1980). Microbial lipids of an intertidal sediment I. Fatty acids and hydrocarbons. Geochim. Cosmochim. Acta 44: 1133-1143

Waslenchuk, D. G., Matson, E. A., Zajac, R. N, Dobbs, F. C., Tramontano, J. M. (1983). Geochemistry of burrow waters vented by a bioturbating shrimp in Bermudian sediments. Mar. Biol. 72: 219-225

Weimer, R. J., Hoyt, J. H. (1964). Burrows of Callianassa major Say, geologic indicators of littoral and shallow neritic environments. J. Paleontol. 38: 761-767

White, D. C. (1986). Quantitative physicochemical characterization of bacterial habitats. In: Poindexter, J. S., Leadbetter, E. R. (eds.) Bacteria in nature, Vol. 2. Plenum, New York, p. $177-203$ 